\title{
COMPENSATORY VALUE OF URBAN TREES IN THE UNITED STATES
}

\author{
by David J. Nowak', Daniel E. Crane ${ }^{2}$, and John F. Dwyer ${ }^{3}$
}

\begin{abstract}
Understanding the value of an urban forest can give decision makers a better foundation for urban tree management. Based on tree-valuation methods of the Council of Tree and Landscape Appraisers and field data from eight cities, total compensatory value of tree populations in U.S. cities ranges from $\$ 101$ million in Jersey City, New Jersey, to $\$ 5.2$ billion in New York, New York. Compensatory values represent compensation to owners for the loss of an individual tree and can be viewed as the value of the tree as a structural asset. Based on national urban forest tree cover data, the total compensatory value for the urban forests of the 48 adjacent United States is estimated at $\$ 2.4$ trillion.
\end{abstract}

Key Words. Urban forestry; urban forest value.

Understanding the value of an urban forest can give managers and planners a basis on which to develop and evaluate programs for managing urban trees. In North America, the most widely used method for estimating the compensatory value of trees was developed by the Council of Tree and Landscape Appraisers (1992). Compensatory values represent compensation to owners for the loss of an individual tree. Compensatory values can be used for estimating compensation for tree losses, justifying and managing resources, and/or setting policies related to the management of urban trees.

Urban forest compensatory values can be used to estimate actual or potential loss caused by catastrophic agents. For example, the loss to the urban forest in Oakland, California, U.S., from a large fire in 1991 was estimated at $\$ 26.5$ million (Nowak 1993b). Compensatory value of potential loss from Asian longhorned beetle (Anoplophora glabripennis) infestation in various U.S. cities ranges between $\$ 72$ million (Jersey City, New Jersey) and $\$ 2.3$ billion (New York, New York) (Nowak et al. 2001c). The estimated maximum potential national urban impact of infestations by $A$. glabripennis is $\$ 669$ billion.

Though some data on compensatory values have been established for individual cities (e.g., Nowak 1993b), individual street tree populations (e.g., Miller and Morano 1984), trees in residential areas (e.g., Martin et al. 1989), and for the total U.S. street tree population
(\$30 billion; Kielbaso 1990), no data exist on the total compensatory value of the entire urban forest resource of the United States. Based on recently collected field data from selected U.S. cities (Nowak and Crane 2000) and analysis of national urban tree cover (Dwyer et al. 2000; Nowak et al. 2001b), this paper estimates total compensatory value of the urban forest resource of the coterminous United States, as well as for eight individual U.S. cities. These data reveal how urban forest structure and value differ across the United States and how valuable the urban forest resource is in terms of its compensatory or structural value. The compensatory value can be viewed as the value of a tree in place in the urban landscape to its owner (i.e., the value of the tree as a structural asset).

\section{METHODS}

Field data were collected to determine the entire urban forest structure (e.g., tree species composition and number of trees on all land uses) of eight cities: Atlanta, Georgia; Baltimore, Maryland; Boston, Massachusetts; Jersey City, New Jersey; New York, NewYork; Oakland, California (Nowak 1993a, b); Philadelphia, Pennsylvania; and Syracuse, New York. Trees in these cities were sampled based on methods developed by the USDA Forest Service for a number of urban forest research projects (e.g., Nowak 1993a, b; Nowak et al. 1998, 2000; Nowak and Crane 2000). These data represent the entire set of comprehensive urban forest structure and monetary value data available for the United States. City tree data [except for Oakland (1989)] were collected between 1996 and 1999 and analyzed using the Urban Forest Effects (UFORE) model based on a stratified random sample of approximately 200 0.04-ha (0.1-ac) plots per city (Nowak and Crane 2000). Data collection included location, species, stem diameter at $1.37 \mathrm{~m}(4.5 \mathrm{ft})$ above the ground $(\mathrm{dbh})$, tree and crown height, crown width, and canopy condition.

The compensatory value of the trees was calculated based on procedures prescribed by the Council of Tree and Landscape Appraisers (CTLA 1992). Compensatory value 
derived using these procedures is regularly used to determine monetary settlement for damage or death of plants through litigation, insurance claims, loss of property value for income tax deductions, and real estate assessments. It is based, in part, on the replacement cost of a similar tree and is an estimate of the amount of money the tree owner should be compensated for tree loss.

CTLA compensatory value calculations are based on four tree and site characteristics: tree trunk area [crosssectional area at $1.37 \mathrm{~m}(4.5 \mathrm{ft})$ above the ground], species, condition, and location. Tree trunk area and species are used to determine the basic value, which is then multiplied by condition and location ratings $(0-1)$ to estimate the final compensatory value of the tree.

For transplantable trees, average replacement cost and transplantable size were obtained from local International Society of Arboriculture publications to determine the basic replacement price (\$ per square unit of cross-sectional area) for the tree. Basic replacement price was multiplied by tree trunk area and species factor $(0-1)$ to determine the tree's basic value. Minimum basic value for a tree $[\mathrm{dbh} \geq$ $2.54 \mathrm{~cm}$ (1 in)], prior to species adjustment, was set at $\$ 150$. Local species values $(0-1)$ were obtained from International Society of Arboriculture publications. If no monetary or species data were available for the state in which the tree was located, data from the closest state were used.

For trees larger than transplantable size:

$$
\begin{gathered}
\text { Basic Value }=\text { Replacement Cost }+ \\
{\left[\text { Basic Price } \times\left(\mathrm{TA}_{\mathrm{A}}-\mathrm{TA}_{\mathrm{R}}\right) \times \text { Species Value }\right]}
\end{gathered}
$$

where replacement cost is the cost of a tree at the largest transplantable size, basic price is the local average cost per unit trunk area $\left(\$\right.$ per $\left.\mathrm{cm}^{2}\right), \mathrm{TA}_{\mathrm{A}}$ is trunk area of the tree being appraised, and $T A_{R}$ is trunk area of the largest transplantable tree. Local average replacement cost, transplantable size, basic price, and species values $(0-1)$ were obtained from International Society of Arboriculture publications. If no data were available for the state, data from the closest state were used.

For trees larger than $76.2 \mathrm{~cm}$ (30 in.) in trunk diameter, trunk area was adjusted downward based on the premise that a large mature tree would not increase in value as rapidly as its trunk area would increase. The following adjusted trunk area formula was determined empirically based on the perceived increase in tree size, expected longevity, anticipated maintenance, and structural safety (CTLA 1992):

$$
\text { Adjusted Trunk Area }=-0.335 d^{2}+176 d-7,020
$$

where $d=$ trunk diameter in $\mathrm{cm}$.

Basic value was multiplied by condition and location factors (0-1) to determine the tree's compensatory value. Condition factors were based on crown dieback: excellent $(<1 \%$ dieback $)=1.0$; good $(1 \%-10 \%$ dieback $)=0.95$; fair $(11 \%-25 \%$ dieback $)=0.82$; poor $(26 \%-50 \%$ dieback $)=$ 0.62 ; critical $(51 \%-75 \%$ dieback $)=0.37$; dying $(76 \%-$ $99 \%$ dieback $)=0.13$; dead $(100 \%$ dieback $)=0.0$.

Available data required using location factors based on land use type (ISA 1988): golf course $=0.8$; commercial/ industrial $=0.75$; cemetery $=0.75$; institutional $=0.75$; parks $=0.6$; residential $=0.6$; transportation $=0.5$; forest $=0.5$; agriculture $=0.4 ;$ vacant $=0.2 ;$ wetland $=0.1$.

As an example of compensatory value calculations, if a 40.6-cm (16-in.) diameter tree $\left(1,295 \mathrm{~cm}^{2}\right.$ trunk area) has a species rating of 0.5 , a condition rating of 0.82 , a location rating of 0.4 , a basic price of $\$ 7$ per $\mathrm{cm}^{2}(\$ 45$ per in $\mathrm{in}^{2}$, and a replacement cost of $\$ 1,300$ for a $12.7-\mathrm{cm}$ (5-in.) diameter tree $\left(127 \mathrm{~cm}^{2}\right.$ trunk area), then the compensatory value would equal:

$$
\begin{gathered}
{[1,300+(7 \times(1,295-127) \times 0.5)] \times 0.82 \times 0.4} \\
=\$ 1,767
\end{gathered}
$$

Data for individual trees in each city were used to determine the total compensatory value for the city. To estimate the compensatory value of urban forests nationally, total compensatory value of each city that had field data was divided by total city tree cover $\left(\mathrm{m}^{2}\right)$ to determine average compensatory value per unit tree cover $\left(\$\right.$ per $\left.\mathrm{m}^{2}\right)$.

The median standardized compensatory value (\$ per $\mathrm{m}^{2}$ ) was multiplied by total urban tree cover in the coterminous United States (Dwyer et al. 2000; Nowak et al. 2001b) to estimate the national compensatory value of urban trees. Tree cover estimates were based on 1991 advanced, very high-resolution radiometer (AVHRR) data (Zhu 1994). Lowest and highest standardized values were used to estimate the potential range of national values. State urban tree cover estimates were multiplied by the median standardized compensatory value to estimate the compensatory value of urban forests in each state.

\section{RESULTS}

Total urban forest compensatory values ranged from $\$ 101$ million in Jersey City, New Jersey, to $\$ 5.2$ billion in New York, New York (Table 1). Average value per urban tree ranged from $\$ 394$ in Atlanta, Georgia, to $\$ 1,187$ in Baltimore, Maryland. Average value per $\mathrm{m}^{2}$ of 
Table 1. Estimated compensatory value (\$), number of trees, tree density (trees/ha), percentage of tree cover, and value per tree and $\mathbf{m}^{2}$ of tree cover for eight U.S. cities.

\begin{tabular}{|c|c|c|c|c|c|c|c|c|c|c|}
\hline \multirow[b]{2}{*}{ City } & \multicolumn{2}{|c|}{$\begin{array}{c}\text { Dollar value } \\
\text { (millions) }\end{array}$} & \multicolumn{2}{|c|}{$\begin{array}{l}\text { No. trees } \\
\text { (thousands) }\end{array}$} & \multicolumn{2}{|c|}{$\begin{array}{l}\text { Trees per } \\
\text { hectare }^{z}\end{array}$} & \multicolumn{2}{|c|}{ Tree cover } & \multicolumn{2}{|c|}{ Dollars per: } \\
\hline & Total & SE & Total & SE & Avg & SE & $\%$ & SE & tree & cover $^{y}$ \\
\hline New York, NY & 5,189 & 688 & 5,212 & 719 & 65 & 9 & 20.9 & 2.0 & 996 & 31.00 \\
\hline Atlanta, GA & 3,710 & 320 & 9,415 & 749 & 276 & 22 & 36.7 & 2.0 & 394 & 29.58 \\
\hline Baltimore, MD & 3,365 & 378 & 2,835 & 605 & 136 & 29 & 25.2 & 2.2 & 1,187 & 63.72 \\
\hline Philadelphia, PA & 1,751 & 172 & 2,113 & 211 & 62 & 6 & 15.7 & 1.3 & 829 & 32.66 \\
\hline Boston, MA & 1,253 & 143 & 1,183 & 109 & 83 & 8 & 22.3 & 1.8 & 1,058 & 39.29 \\
\hline Oakland, $\mathrm{CA}^{\mathrm{x}}$ & 757 & 30 & 1,588 & 51 & 120 & 4 & 21.0 & 0.2 & 477 & 27.23 \\
\hline Syracuse, NY & 525 & 54 & 891 & 125 & 137 & 19 & 24.4 & 2.0 & 590 & 33.13 \\
\hline Jersey City, NJ & 101 & 12 & 136 & 22 & 36 & 6 & 11.5 & 1.2 & 742 & 22.98 \\
\hline
\end{tabular}

${ }^{\mathrm{z}}$ Multiply by 2.471 to convert to trees per acre.

y Dollars per square meter of tree cover (multiply by 0.093 to convert to $\$ / \mathrm{ft}^{2}$ of cover).

${ }^{x}$ Based on original estimates for entire tree population ( 1.587 million trees; $\$ 385$ million) (Nowak $\left.1993 \mathrm{~b}\right)$ using a basic price of $\$ 4.18$ per $\mathrm{cm}^{2}$ ( $\$ 27$ per in ${ }^{2}$ )

that was adjusted upward based on a more recent basic price of $\$ 8.22$ per $\mathrm{cm}^{2}$ ( $\$ 53$ per in ${ }^{2}$ ) for California.

tree cover ranged from $\$ 22.98$ in Jersey City to $\$ 63.72$ in Baltimore (Table 1). Based on the individual city compensatory values per $\mathrm{m}^{2}$ of tree cover, the total compensatory value of urban trees in the coterminous United States is estimated at $\$ 2.42$ trillion, with bounds on the estimation between $\$ 1.75$ trillion and $\$ 4.85$ trillion. States with the highest estimated urban forest compensatory values are Georgia, Alabama, and Ohio (Table 2).

\section{DISCUSSION}

The urban forests of the United States are a valuable resource with approximately 3.8 billion trees (Dwyer et al. 2000; Nowak et al. 2001b) and an average compensatory value of approximately $\$ 630$ per tree. Total tree values for a city will vary based on the total number and location of trees in the city, species composition, diameter distribution, and tree condition. Increased number of trees and a greater proportion of healthy trees, largediameter trees, high-value species, and/or trees in more valuable locations (e.g., golf courses, institutional lands) will lead to greater urban forest compensatory values.

State compensatory tree values (Table 2 ) are based on extrapolations of median sample values $\left(\$\right.$ per $\mathrm{m}^{2}$ of tree cover) to state tree cover estimates (Dwyer et al. 2000; Nowak et al. 2001b). These state values are approximations based on limited samples; actual state values could vary significantly from these estimates based on specific species, diameter distribution, and tree health found within urban areas in the state. More data are needed to help quantify urban forest structure, health, functions, and value at the state level, as well as how urban forests are changing through time. A USDA Forest Service National Urban Forest Monitoring Program is being pro- posed and tested to help obtain these necessary longterm data (Nowak et al. 2001a).

Extrapolations of compensatory values to urban forests at the city or neighborhood scale based on data provided in this manuscript should be done with caution because individual forest structures and values can vary considerably at the local scale. Based on the data from the eight cities analyzed, overall citywide compensatory values ranged between $\$ 23$ to $\$ 64$ per $\mathrm{m}^{2}$ ( $\$ 2.1$ to $\$ 5.9$ per $\mathrm{ft}^{2}$ ) of tree cover. However, $75 \%$ of the city values were between $\$ 27$ and $\$ 39$ per $\mathrm{m}^{2}$ ( $\$ 2.5$ and $\$ 3.6$ per $\mathrm{ft}^{2}$ ) of cover. Extrapolation of values to other cities should be based on values from cities in the same region with similar structural characteristics.

Compensatory values are one of several ways by which urban forests can be valued. Compensatory values are based, in part, on replacement costs and are related to compensation of owners for tree loss. The estimates of compensatory value are an approximation of the structural asset value of a tree with a specific species, size, condition, and location.

The values of urban forests can also be estimated based on the functions that they perform (e.g., aesthetics, pollution removal, temperature modification). These functional values are only indirectly related to the compensatory value of the tree. In general, the greater the compensatory value of the forest (i.e., increased numbers of trees, tree size, and better tree health), the greater the ability of the forest to produce functional benefits.

As an illustration of these two types of tree value (compensatory and functional), consider a factory (with a replacement cost of $\$ 1$ million) that produces 10,000 widgets per year with a net profit of $\$ 100,000$ per year. 
Table 2. Estimated compensatory value by state, including percentage of urban tree cover, amount of urban land, and proportion of state in urban land.

\begin{tabular}{|c|c|c|c|c|}
\hline State & $\begin{array}{l}\text { Compensatory } \\
\text { value } \\
\text { (millions) }\end{array}$ & $\begin{array}{l}\text { Urban } \\
\text { tree cover } \\
(\%) \\
\end{array}$ & $\begin{array}{l}\text { Urban } \\
\text { area }^{z} \\
\left(\mathrm{~km}^{2}\right) \\
\end{array}$ & $\begin{array}{l}\text { Portion of } \\
\text { state } \\
(\%) \\
\end{array}$ \\
\hline Georgia & 146,765 & 55.3 & 8,338 & 5.4 \\
\hline Alabama & 130,208 & 48.2 & 8,487 & 6.3 \\
\hline Ohio & 120,970 & 38.3 & 9,923 & 8.5 \\
\hline Florida & 107,805 & 18.4 & 18,407 & 10.8 \\
\hline Tennessee & 103,151 & 43.9 & 7,382 & 6.8 \\
\hline Virginia & 99,652 & 35.3 & 8,869 & 8.0 \\
\hline Illinois & 98,310 & 33.7 & 9,165 & 6.1 \\
\hline California & 94,883 & 10.9 & 27,348 & 6.4 \\
\hline Pennsylvania & 91,571 & 34.4 & 8,363 & 7.0 \\
\hline New Jersey & 91,136 & 41.4 & 6,916 & 30.6 \\
\hline Texas & 88,811 & 10.5 & 26,573 & 3.8 \\
\hline North Carolina & 87,652 & 42.9 & 6,419 & 4.6 \\
\hline New York & 84,776 & 26.3 & 10,127 & 7.2 \\
\hline Minnesota & 80,652 & 37.4 & 6,775 & 3.0 \\
\hline Michigan & 70,845 & 29.7 & 7,494 & 3.0 \\
\hline Montana & 68,635 & 49.4 & 4,365 & 1.1 \\
\hline Washington & 60,736 & 33.6 & 5,679 & 3.1 \\
\hline Maryland & 57,756 & 40.1 & 4,525 & 14.1 \\
\hline Massachusetts & 55,509 & 25.3 & 6,893 & 25.2 \\
\hline South Carolina & 55,487 & 39.8 & 4,380 & 5.3 \\
\hline Missouri & 55,080 & 30.6 & 5,655 & 3.1 \\
\hline Indiana & 49,655 & 31.2 & 5,000 & 5.3 \\
\hline Maine & 43,833 & 47.7 & 2,887 & 3.1 \\
\hline Louisiana & 43,277 & 25.3 & 5,374 & 4.0 \\
\hline Mississippi & 41,344 & 38.6 & 3,365 & 2.7 \\
\hline Wisconsin & 37,488 & 25.8 & 4,565 & 2.7 \\
\hline Oklahoma & 36,646 & 14.5 & 7,940 & 4.4 \\
\hline Kentucky & 35,870 & 33.4 & 3,374 & 3.2 \\
\hline Arizona & 33,449 & 11.4 & 9,218 & 3.1 \\
\hline Iowa & 33,166 & 33.1 & 3,148 & 2.2 \\
\hline Connecticut & 28,346 & 21.8 & 4,085 & 28.5 \\
\hline Arkansas & 27,334 & 25.0 & 3,435 & 2.5 \\
\hline New Hampshire & 26,225 & 49.1 & 1,678 & 6.9 \\
\hline Oregon & 22,062 & 30.4 & 2,280 & 0.9 \\
\hline Colorado & 17,979 & 13.0 & 4,345 & 1.6 \\
\hline Kansas & 16,802 & 20.5 & 2,575 & 1.2 \\
\hline West Virginia & 14,587 & 42.2 & 1,086 & 1.7 \\
\hline Utah & 11,484 & 14.0 & 2,577 & 1.2 \\
\hline Nevada & 10,068 & 9.9 & 3,195 & 1.1 \\
\hline Delaware & 8,341 & 46.3 & 566 & 8.8 \\
\hline Idaho & 7,871 & 25.6 & 966 & 0.4 \\
\hline Nebraska & 7,126 & 21.1 & 1,061 & 0.5 \\
\hline Vermont & 4,767 & 36.0 & 416 & 1.7 \\
\hline South Dakota & 3,771 & 19.2 & 617 & 0.3 \\
\hline New Mexico & 3,538 & 4.8 & 2,316 & 0.7 \\
\hline Rhode Island & 2,623 & 8.9 & 926 & 23.2 \\
\hline North Dakota & 1,135 & 7.8 & 457 & 0.2 \\
\hline Wyoming & 913 & 3.6 & 797 & 0.3 \\
\hline Total, U.S.y & $2,423,886$ & 27.1 & $281,000^{x}$ & 3.5 \\
\hline
\end{tabular}

${ }^{2}$ Includes land and water.

'U.S. total includes the District of Columbia but not Alaska and Hawaii.

Includes $492 \mathrm{~km}^{2}$ that crossed state borders and could not be assigned to an individual state.
The value of the physical structure of the factory is based on the cost to rebuild or replace the factory with a similar structure. The factory also has an additional value based on the potential or actual profits of the factory outputs. The value of the factory structure ( $\$ 1$ million) is comparable to the compensatory value of the forest. The net profit $(\$ 100,000$ per year) is analogous to the functional value of the forest. Compensatory value is based on the structure in place as an asset, while the functional value is an annual value based on the various functions of the particular structure. Trees can have negative functional values (e.g., trees can increase annual building energy use in certain locations), which are analogous to monetary losses in factories. Similar to factories, trees also have various maintenance costs, which are essential for maintaining overall functional benefits or profits. Management of urban forests is needed to enhance functional values and improve human health and well-being, and environmental quality in cities. Maximizing net functional benefits of the urban forest will lead to the greatest value to society.

To more effectively estimate the functional values of urban forests, research is needed on how urban forest structure affects functions (e.g., how differing amounts, species, locations, sizes, and other factors of trees affect air pollution) and what value society places on these functions. Research on some of the functional benefits and values of urban forests has begun (air pollution removal, carbon storage, energy conservation), but other functional values still need to be quantified with reference to urban forest structure (e.g., aesthetic values, social and community values, wildlife values). As an example of func- 
tional values of urban forests, it is estimated that urban trees in the coterminous United States currently store 700 million metric tons (775 million tons) of carbon ( $\$ 14,300$ million value) with a gross carbon sequestration rate of 22.8 million metric tons of carbon per year (25.1 million tons carbon per year) ( $\$ 460$ million per year) (Nowak and Crane 2002).

The compensatory and functional values of the urban forest should ultimately link together. An individual being compensated for tree loss should also be compensated for the loss of functions that the tree would have provided over time (similar to loss of profit from a factory). With information on flow of benefits over the life of a tree and the functional values that they generate, a total compensation of loss (both structural and functional) could then be calculated for trees. Such calculations would require information on tree growth and life spans, as well as adjustments of future values back to present values using an interest rate. For example, a factory with a continuous annual net profit of $\$ 100,000$ and a cost of capital of $10 \%$ has a present value of a flow of benefits over time of $\$ 1,000,000$. This present value is equivalent to the total functional value of the factory. However, given the diversity and complexity of the urban forest and the numerous benefits it provides, and the difficulty in estimating total monetary benefits from particular urban forest structures, comprehensive functional valuation of the urban forest resource will be difficult.

Another complication in comparing CTLA-based compensatory values with the functional values of trees concerns who receives the compensation. The CTLA approach is aimed at estimating the compensatory or structural value of the tree for the tree owner. However, various functional benefits have values to a wide range of urban residents; benefits such as cooler air temperatures and aesthetics may accrue to those who live in the local neighborhood, while benefits such as improved air quality may have a wider regional impact. Given the current state of knowledge and difficulty in quantifying functional benefits, it is important to recognize the differences between compensatory (or structural) and functional values of the urban forest and their possible linkages.

\section{CONCLUSION}

The urban forest resource in the United States is significant, not only in terms of numbers of trees and extent of canopy but also in terms of the value of this resource and the numbers of people it affects. Based on CTLA methodology, the physical resource (or tree infrastruc- ture) of the urban forest nationwide has a compensatory value of more than $\$ 2$ trillion. In addition, this resource annually provides numerous functions that significantly affect human health and environmental quality in and around urban areas and generate large functional values. The structural (or compensatory) value and functional values of the urban forest provide useful guides for urban forest resource management.

\section{LITERATURE CITED}

Council of Tree and Landscape Appraisers (CTLA). 1992. Guide for Plant Appraisal (8th ed.). International Society of Arboriculture, Champaign, IL.

Dwyer, J.F., D.J. Nowak, M.H. Noble, and S.M. Sisinni. 2000. Connecting People with Ecosystems in the 21st Century: An Assessment of Our Nation's Urban Forests. General Technical Report PNW-GTR-490, USDA Forest Service, Pacific Northwest Research Station, Portland, OR.

International Society of Arboriculture (ISA). 1988. Valuation of Landscape Trees, Shrubs, and Other Plants. International Society of Arboriculture, Champaign, IL.

Kielbaso, J.J. 1990. Trends and issues in city forests. J. Arboric. 16:69-73.

Martin, C.W., R.C. Maggio, and D.N. Appel. 1989. The contributory of trees to residential property in the Austin, Texas, metropolitan area. J. Arboric. 15(3):72-76.

Miller, R.W., and M.S. Morano. 1984. URFOR/SIMULATION: An urban forest management computer simulation/game. J. Arboric. 10:55-63.

Nowak, D.J. 1993a. Atmospheric carbon reduction by urban trees. J. Environ. Manage. 37(3):207-217.

Nowak, D.J. 1993b. Compensatory value of an urban forest: An application of tree-value formula. J. Arboric. 19(3):173-177.

Nowak, D.J., and D.E. Crane. 2000. The urban forest effects (UFORE) model: Quantifying urban forest structure and functions, pp 714-720. In Hansen M., and T. Burk (Eds.). Proceedings: Integrated Tools for Natural Resources Inventories in the 21st Century. IUFRO Conference, 16-20 August 1998, Boise, ID. General Technical Report NC-212, USDA Forest Service, North Central Research Station, St. Paul, MN.

Nowak, D.J., and D.E. Crane. 2002. Carbon storage and sequestration by urban trees in the USA. Environ. Pollut. 116(3):381-389.

Nowak, D.J., D. Twardus, and C.T. Scott. 2001a. Proposal for urban forest health monitoring in the United States, pp 178-183. In 2000 Society of American Foresters National Conference Proceedings. Washington, DC.

Nowak, D.J., M.H. Noble, S.M. Sisinni, and J.F. Dwyer. 2001b. Assessing the U.S. urban forest resource. J. For. 99(3):37-42.

Nowak, D.J., J. Pasek, R. Sequeira, D.E. Crane, and V. Mastro. 2001c. Potential effect of Anoplophora glabripennis (Coleoptera: Cerambycidae) on urban trees in the United States.J. Econom. Entomol. 94(1):16-22. 
Nowak, D.J., K.L. Civerolo, S.T. Rao, G. Sistla, C.J. Luley, and D.E. Crane. 2000. A modeling study of the impact of urban trees on ozone. Atmos. Environ. 34:1601-1613.

Nowak, D.J., P.J. McHale, M. Ibarra, D. Crane, J. Stevens, and C. Luley. 1998. Modeling the effects of urban vegetation on air pollution, pp 399-407. In Gryning, S.E., and N. Chaumerliac (Eds.). Air Pollution Modeling and Its Application XII. Plenum Press, New York, NY.

Zhu, Z. 1994. Forest Density Mapping in the Lower 48 States: A Regression Procedure. Res. Pap. SO-280. USDA Forest Service, Southern Forest Experiment Station, New Orleans, LA.

Acknowledgments. We thank Chris Luley for assistance with field data collection and model inputs, and Paul Gobster and Gary Watson for review of this manuscript. This work was funded, in part, by the USDA Forest Service's RPA Assessment Staff, and State and Private Forestry, Cooperative Forestry's Urban and Community Forestry Program. Data collection in Baltimore, funded by the USDA Forest Service, is part of the National Science Foundation's Long-Term Ecosystem Research project. Data from Jersey City were collected and analyzed in cooperation with the State of New Jersey, Department of Environmental Protection and Energy, Division of Parks and Forestry.

\section{${ }^{1 *}$ Project Leader \\ ${ }^{2}$ Computer Specialist \\ USDA Forest Service, Northeastern Research Station \\ c/o 5 Moon Library, SUNY-ESF}

Syracuse, NY 13210, U.S.

\section{${ }^{3}$ Project Leader}

USDA Forest Service, North Central Research Station

845 Chicago Ave., Suite 225

Evanston, IL 60202-2357, U.S.

\section{* Corresponding author.}

Résumé. Comprendre la valeur d'une forêt urbaine peut donner aux décideurs une meilleure base pour la gestion des arbres en milieu urbain. En se basant sur les méthodes d'évaluation du Comité des évaluateurs en arbres et aménagement paysager (Council of Tree and Landscape Appraisers, CTLA) et sur des données terrain de huit villes, la valeur contributive totale des arbres dans les villes américaines se situe entre $\$ 101$ millions pour la ville de New Jersey au New Jersey et $\$ 5,2$ milliards pour la ville de New York dans l'état de New York. La valeur contributive représente le montant compensatoire qui peut être accordé à un propriétaire pour la perte d'un de ses arbres et elle peut être perçue comme la valeur de l'arbre comme composante physique. En se basant sur les données nationales du couvert forestier, la valeur contributive totale des forêts urbaines des 48 états américains continentaux (à l'exception de Hawaï et de l'Alaska) est estimée à 2,4 trillions de dollars.

Zusammenfassung. Das Verständnis für den Wert eines Stadtwaldes kann den Entscheidungsträgern eine bessere Grundlage für ein urbanes Grünflächen-Management geben. Basierend auf den Felddaten und Baumbewertungsmethoden der Baum- und Landschaftsbewertung aus 8 Städten, rangierte der totale kompensierte wert der Baumpopulation in amerikanischen Städten von $\$ 101$ Millionen in New Jersey bis zu $\$ 5.2$ Milliarden in New York City. Der kompensierte Wert repräsentiert eine Kompensation an Besitzer für den Verlust eines individuellen Baumes und kann als Baumwert im Sinne Strukturerfassung betrachtet werden. Basierend auf Erhebungsdaten über nationale Baumbedeckung beträgt der kompensatorische Wert der Stadtwälder der 48 benachbarten Staaten der USA schätzungsweise \$2.4 Trillionen

Resumen. El entendimiento del valor de un bosque urbano puede dar a los tomadores de decisiones una base mejor para el manejo. Con base en tres métodos de evaluación del "Council of Tree and Landscape Appraisers" y datos de campo de ocho ciudades, se efectuó el cálculo del valor compensatorio total de las poblaciones de árboles de ciudades los E.U. Desde 101 millones de dólares en Jersey City, New Jersey, hasta 5.2 billones en New York, New York. Estos valores representan la compensación a los propietarios por la pérdida de árboles individuales y pueden ser vistos como el valor de los árboles como un bien arquitectónico. Con base en datos nacionales de cobertura forestal urbana, el valor compensatorio total para 48 bosques urbanos de los Estados unidos se estimó en 2.4 trillones de dólares. 